\title{
Concentration of collagen fibers in the musculature of broiler chickens fed with cupuacu seed by-product
}

[Concentração de fibras colágenas na musculatura de frangos alimentados com farinha de cupuaçu]

\author{
T.B. Silveira ${ }^{1}$, S.F.Souza ${ }^{1}$, L.S. Medeiros ${ }^{1}$, H.J. Freitas ${ }^{1}$, R.E. Gracci ${ }^{2}$, \\ M.A. Miglino ${ }^{2}$, Y.K. Carvalho ${ }^{*}$ \\ ${ }^{1}$ Universidade Federal do Acre - Rio Branco, AC \\ ${ }^{2}$ Universidade de São Paulo - São Paulo, SP
}

\begin{abstract}
In this essay, we quantify the concentration of collagen fibers in broiler chickens exposed to increasing concentrations of cupuacu seed by-product. Collection of material was carried out in five chickens per treatment at 70 days old in the groups: control, $5 \%$ and $10 \%$ inclusion of cupuacu seed by-product. Fragments of Thoracic Pectoralis (PT) and Iliotibial lateralis (ITL) muscles were prepared for light and electronic microscopy. The amount of collagen fibers in the muscle groups was $1.08 \pm 0.61 \%$ in the PTC group; $6.24 \pm 2.58 \%$ in PT5\% and $7.30 \pm 2.75 \%$ in PT10\%. In the Iliotibial Lateralis groups, the results were $6.96 \pm 3.14 \%$ in the ITLC; $7.43 \pm 4.22 \%$ in the ITL5\% and $8.66 \pm 2.35 \%$ in ITL10\%. The amount of collagen fibers in the ITL5\% and ITL10\% groups showed no significant statistical difference. However, when compared to the ILTC group, there was a significant statistical difference. The PT muscle responds to standard nutritional changes, unlike the ILT muscle, which requires a high-nutrient formulation. The use of 5\% cupuacu seed by-product has proven to be a viable alternative source of animal feed, as it promotes an increase in the concentrations of collagen fibers in the musculature of broiler chickens and is possibly the determining factor in meat texture.
\end{abstract}

Keywords: broiler chickens, collagen, Theobroma grandiflorum

\section{RESUMO}

Neste estudo, foram quantificadas as concentrações de fibras colágenas de frangos expostos a crescentes concentrações de farinha de cupuaçu. A coleta de material foi realizada em cinco animais por tratamento, aos 70 dias de idade, nos grupos: controle, inclusão de 5\% e de 10\% de farinha de cupuaçu. Fragmentos dos músculos peitoral torácico (PT) e iliotibial lateral (ITL) foram preparados para microscopia de luz e eletrônica. A quantidade de fibras colágenas nos grupos foi: 1,08 $\pm 0,61 \%$ no grupo

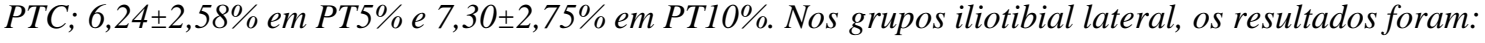
$6,96 \pm 3,14 \%$ no ITLC; $7,43 \pm 4,22 \%$ no ITL5\% e 8,66 $2,35 \%$ em ITL10\%. A quantidade de fibras colágenas nos grupos ITL5\% e ITL10\% não apresentou diferença estatística significativa. No entanto, quando comparados ao grupo ILTC, houve diferença estatística significativa. $O$ músculo PT responde a mudanças nutricionais padrão, ao contrário do músculo ILT, que requer alta formulação nutricional. $O$ uso de $5 \%$ de farinha de cupuaçu provou ser uma fonte alternativa viável de alimentação animal, pois promove um aumento nas concentrações de fibras de colágeno na musculatura de frangos de corte e é possivelmente um fator determinante na textura da carne.

Palavras-chave: frangos, colágeno, Theobroma grandiflorum

\section{INTRODUCTION}

In Brazil, according to Lima Filho et al. (2004), there is a large market for the consumption of

Recebido em 27 de dezembro de 2017

Aceito em 4 de dezembro de 2018

*Autor para correspondência (corresponding author)

E-mail: ykaracas@yahoo.com.br broiler chicken. Animal feed represents $70 \%$ of the production cost of this meat and consequently there is pressure to seek alternative food sources in order to reduce costs and make production more efficient. Cupuacu (Theobroma grandiflorum, Schum) is a typical fruit of the 
Amazon region and it currently shows great potential for the industry as a result of its high and growing consumption. It is known that cupuacu seeds have considerable nutritional value, but they are still commonly discarded or used as fertilizers (Carvalho et al., 2009).

Muscle texture is directly influenced by the amount of collagen fibers (Watanabe et al., 2015) and they vary in proportion in the muscle composition according to the location and functional property of the muscle (Sakakibara et al., 2000; Listrat et al., 2016). Currently, there are studies that have analyzed the amount of these collagen fibers in muscles of bovines (Heinemann et al., 2003; Alves et al., 2005, Hadlich et al., 2006; Lima Junior et al., 2011) and swines (Nakamura et al., 2003). However, there is little evidence regarding the presence of collagen fibers in the musculature of broiler chickens (Takahashi et al., 2006; Carvalho et al., 2013). Thus, the objective of this study was to quantify this protein in the musculature of broiler chickens fed with different concentrations of cupucu seed by-product.

\section{MATERIALS AND METHODS}

This study was conducted at the Federal University of Acre (UFAC) in the Animal Anatomy Laboratory of the Center of Biological and Natural Sciences, and it was approved by the Animal Ethics Committee of UFAC (under protocol No. 017/2014). Thirty broiler chickens were used, in confinement. They were housed at 1 day old in six (06) boxes, each one containing five (05) animals. During the experimental period, the animals received water ad libidum and a certain type of feedstuff, namely: Control (feedstuff based on corn and soybean meal); $5 \%$ (including 5\% cupuacu-seed cake); $10 \%$ (including 10\% cupuacu-cake). The experimental rations (initial, growth and final) were formulated according to Rostagno et al. (2011)

Slaughter was carried out at 70 days old, in order to collect samples for analysis, which were identified as Thoracic Pectoralis (PT) and Iliotibial lateralis (ITL) muscles. The fragments were placed in $10 \%$ formaldehyde for $48 \mathrm{~h}$ and then in ethyl alcohol at $70 \%$ to achieve conventional histological processing for light microscopy. They were washed in running water for two hours and dehydrated in a series of increasing alcohol concentrations $\left(70^{\circ}, 95^{\circ}\right.$ and $100^{\circ} \mathrm{GL}$ ), in a total of five hours; samples were cleared in xylene-alcohol $(1: 1)$ and xylene for four hours and embedded in paraffin blocks, thus resulting in 5-micrometer-thick slices.

The samples were then stained with Picrosirius Red (for evaluation of collagen fibers). After staining, the samples were analyzed with the aid of an optical microscope, which was used to obtain the photomicrograph for documentation using a ZEISS Axioskop microscope with attached camera and software for morphometry (K-400 ZEISS ${ }^{\circledR}$ ).

Next, $1.0 \mathrm{~cm}-$ length fragments were collected from PT and ITL muscles, which were washed in distilled water for 20 minutes and then fixed in Osmium tetroxide solution at $1 \%$ (OsO4, Polyscience ${ }^{\circledR}$ Inc., USA) for 2 hours. Subsequently, the fragments were serially dehydrated in ethanol of increasing concentration $(50 \%$ to $100 \%)$ for 30 minutes in each concentration and dried using a Balzers CPD 020 (FMVZ/USP) critical point drier. Samples were placed in metal aluminum bases (stubs), using carbon adhesive, coated with gold using an EMITECH K550 (FMVZ/USP) coater and a photographic record made from a scanning electron microscope (Morgagni 268D Phillips $\left.{ }^{\circledR}\right)$, at the College of Veterinary Medicine and Animal Science, University of São Paulo.

Statistical analyses were performed by the method of analysis of variance (ANOVA) and Tukey's test at $5 \%$ probability in order to check for significant differences between the means.

\section{RESULTS}

An analysis of the arrangement of collagen fibers in Thoracic Pectoralis (PT) and Iliotibial lateralis (ILT) muscles showed that they are arranged primarily in the portions of the endomysium and perimysium, which make up the connective tissue (Figure 1). 


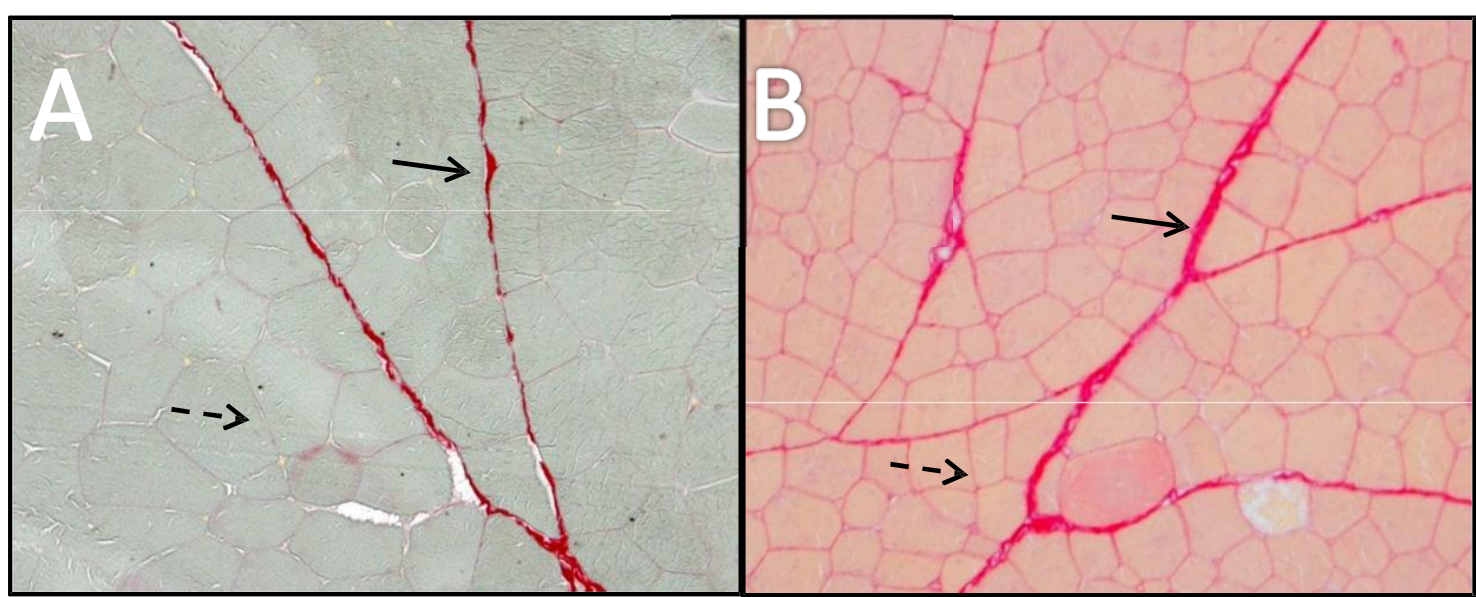

Figure 1. Cross-sectional photomicrograph of muscles of broiler chickens (40x power) stained with Picrosirius Red (A) and Picrosirius Red with hematoxylin background (B), indicating collagen fibers present between the muscle fibers (Endomysium - dotted arrow) and between the muscle fiber groups (Perimysium - full arrow).

After processing the samples, the percentage (mean \pm standard deviation) of collagen fibers in the muscle groups was $1.08 \pm 0.61 \%$ in the PTC group; $6.24 \pm 2.58 \%$ in PT5\% and $7.30 \pm 2.75 \%$ in PT10\%. In Iliotibial lateralis groups, the results were $6.96 \pm 3.14 \%$ in the ITLC; $7.43 \pm 4.22 \%$ in ITL5\% and $8.66 \pm 2.35 \%$ in ITL10\%. The results found after statistical analysis of collagen fiber concentrations of PT groups produced two findings: the PTC group differed from the PT5\% and PT10\% groups (Figure 2), and there was no significant difference between the PT5\% and PT10\% groups (Table 1).

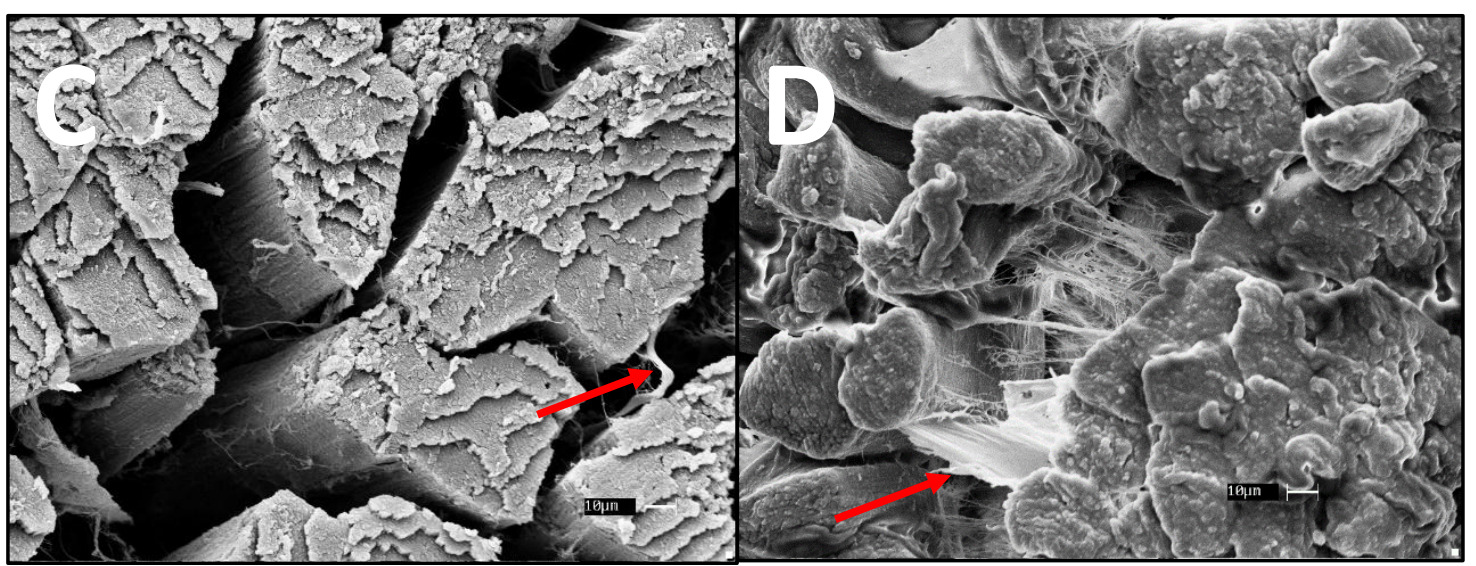

Figure 2. Histological photomicrograph of the thoracic pectoralis muscle (PT) of Label Rouge in the control group (C) and the group treated with $10 \%$ cupuacu flour (D). The PT C group differs significantly from the other groups analyzed; there are a larger number of collagen fibers in the latter.

Table 1. Concentration values (mean \pm standard deviation) of collagen fibers in the Deep Pectoral muscle and Iliotibial lateralis in broiler chicken according to the treatments

\begin{tabular}{lccc}
\multicolumn{1}{c}{ Muscle / Treatment } & Control & $5 \%$ & $10 \%$ \\
\hline Deep Pectoral (PT) & $1.08 \pm 0.61^{\mathrm{a}}$ & $6.24 \pm 2.58^{\mathrm{b}}$ & $7.30 \pm 2.75^{\mathrm{b}}$ \\
Iliotibial lateralis (ILT) & $6.96 \pm 3.14^{\mathrm{c}}$ & $7.43 \pm 4.22^{\mathrm{c}}$ & $8.66 \pm 2.35^{\mathrm{c}}$ \\
\hline
\end{tabular}

$\mathrm{a}, \mathrm{b}, \mathrm{c}-$ Statistical difference 
The collagen fiber concentrations measured in the samples of the Iliotibial lateralis muscle showed no significant difference between the ITLC, ITL5\% and ITL10\% groups (Figure 3). On the other hand, when comparing PTC and ITLC groups, there was a significant difference

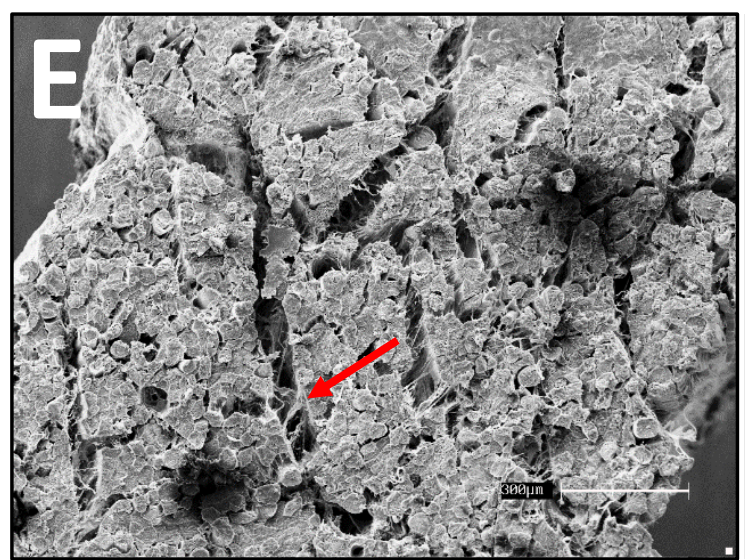

between the concentrations of collagen fibers. When the comparison was made between PT 5\% and ITL 5\%, there was no significant difference between the samples; the same result was observed in the analysis of PT $10 \%$ and ITL $10 \%$.

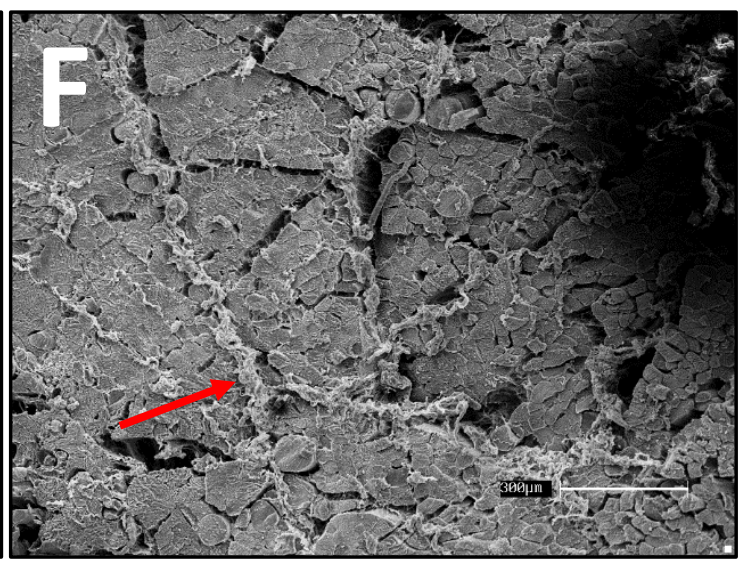

Figure 3. Electron microscopy cross-section scanning of the Iliotibial lateralis muscle (ITL) of broiler chicken in the control group (E) and group treated with $10 \%$ cupuacu flour $(\mathrm{F})$. There was no significant difference between the samples. Collagen fibers $=$ Red Arrow.

\section{DISCUSSION}

The muscles used for this study were the Deep Pectoral muscle and Iliotibial Lateralis, which respectively represented white meat and red meat, the same ones used by Sakakibara et al. (2000), Voutila et al. (2009), Souza et al. (2012), Carvalho et al. (2013) and Mobini (2015). These muscle groups were chosen because of their relevance as valuable parts of chicken meat (Osera et al., 2008).

The arrangement of the collagen fibers was shown to be equal between the endomysium and perimysium, a fact that corroborates the findings of Voutila (2009), Carvalho et al. (2013) and Mobini (2015). According to Zanusso \& Dionello (2003) and Purslow (2005), the properties of the connective tissue present in the musculature influence meat tenderness.

Nishimura et al. (1996), Sakakibara et al. (2000) and Purslow (2005) found that the variations between the concentrations of collagen fibers can occur due to several factors, which include: different strains contained within the species; variations between the same muscles of the same species and; different muscles of the same animal. This information corroborates with the findings of the present study, since the muscles which were used to evaluate concentration of collagen fibers have distinct functional properties as well as differentiated anatomical locations.

Based on this principle, Voutila (2009) showed that the concentration of collagen fibers present in the muscles of the lower limbs is greater than the ones present in the pectoral muscles. This information explains the results found in our study, as the ITL groups had higher concentrations of collagen fibers when compared with the PT groups.

An analysis of the ITL groups showed that there was no significant change between concentrations in ITLC, ITL5\% and ITL10\% groups. A fact, which is explained by the reports presented by Tesseraud et al. (1996) and Das et al. (2008), since the thoracic pectoralis muscle in these animals has a great response to standard nutritional changes, unlike Iliotibial lateralis muscle, which requires a high-nutrient formulation.

Assuming that bromatological composition of different diets can influence the collagen fibers, it also can explain the discrepancy between concentrations of PTC group with some other 
studies. Results found by Das et al. (2010) for means of collagen fibers in the pectoralis muscle were similar to those found in the present study. In the studies of Carvalho et al. (2013), however, although the same strain of animals (Label Rouge) has been used in both studies, there were differences between the means presented. The PT5\% and PT10\% groups showed to have higher means than the PTC group, hence one may state that the use of cupuacu seed by-product added to the feed of broiler chickens leads to an increase in the concentration of collagen fibers in the muscle. Muscle fibers are surrounded by connective tissues, which is composed mainly of collagen and also of proteoglycans and glycoproteins, which contribute to meat texture. Despite several studies attempting to establish the role of collagen in texture of meat, this influence has not been well defined yet (Nishimura et al., 2010). Nevertheless, it is known that this increase in the concentration of collagen fibers influences the texture of meat, which was given by the increase in tenderness (Weston et al. 2002; Brooks and Savell, 2003; Nakamura et al., 2003; Ramos and Gomide, 2007; An et al., 2010). In this sense, Glitsh (2000) and Yamauchi et al. (2014) stated that tenderness is the most important characteristic that affects perceptions of meat quality. Meat characteristics as juiciness and flavor, also determine meat palatability. However, it has already been shown that tenderness is the main cause of consumer dissatisfaction.

The inclusion of 5\% and $10 \%$ cupuacu seed byproduct in the broiler chickens' lineage did not differ statistically from each other, demonstrating that it is not necessary to use high concentrations of this product in animal feed. While conducting this research, there were no studies that assessed the relationship between feeding chickens and concentration of collagen fibers present in the muscles, hence this is the first record of such an approach.

\section{CONCLUSION}

The use of $5 \%$ cupuacu seed by-product promoted an increase of collagen fiber concentrations in muscles of broiler chickens and it is probably the determining factor in meat texture. Thus, using this by-product is a good alternative in the feeding of animals.

\section{REFERENCES}

ALVES, D.D.; GOES, R.H.T.B.; MANCIO, A.B. Maciez da carne bovina. Ciênc. Anim. Bras., v.6, p.135-149, 2005.

AN, J.Y.; ZHENG, J.X.; LI, J.Y. et al. Effect of myofiber characteristics and thickness of perimysium and endomysium on meat tenderness of chickens. Poult. Sci., v.89, p.1750-1754, 2010.

BROOKS, J.C.; SAVELL, J.W. Perimysium thickness as an indicator of beef tenderness. Meat Sci., v.67, p.329-334, 2003.

CARVALHO, A.V.; GARCIA, N.H.P.; FARFÁN, J.A.; WADA, J.K.A. Caracterização de concentrado e isolado proteico extraído de sementes de cupuaçu (Theobroma grandiflorum, Schum). Braz. J. Food Technol., v.12, p.1-8, 2009.

CARVALHO, Y.K.; MEDEIROS, L.S.; ZAVARIZE, K.C. et al. Avaliação quantitativa de fibras colágenas no músculo de frango caipira (Label Rouge e Pedrês). Rev. Biotemas, v.26, p.123-127, 2013.

DAS, C.; ROY, B.C.; OSHIMA I. et al. Carcass composition and skeletal muscle distribution in the broilers produced under different nutritional regimes1. Male chicks at three weeks of age. J. Fac. Agricult., v.53, p.43-47, 2008.

DAS, C.; ROY, B.C.; OSHIMA, I. et al. Collagen content and architecture of the pectoralis muscle in male chicks and broilers reared under various nutritional conditions. Anim. Sci. J., v.81, p.252-263, 2010.

GLITSH, K. Consumer perceptions of fresh meat quality: cross-national comparison. Br. Food J., v.102, p.177-194, 2000.

HADLICH, J.C.; MORALES, D.C.; SILVEIRA, A.C. et al. Efeito do colágeno na maciez da carne de bovinos de distintos grupos genéticos. Acta Sci. Anim. Sci., v.28, p.57-62, 2006.

HEINEMANN, R.J.B.; PINTO, M.F.; ROMANELLI, P.F. Fatores que influenciam a textura da carne de novilhos Nelore e cruzados Limousin-nelore. Pesqui. Agropecu. Bras., v.38, p.963-971, 2003.

LIMA FILHO, D.O.; SPROESSES, R.L.; MAIA, F.S.; BISCOLA, L.A.G. Comportamento do consumidor de alimentos: uma perspectiva da nova carne de galinha caipira. In: CONGRESSO DA SOCIEDADE BRASILEIRA DE ECONOMIA, ADMINISTRAÇÃO E SOCIOLOGIA RURAL, 52., 2004, Cuiabá. Anais... Cuiabá: SOBER, 2004.

LIMA JUNIOR, D.M.; RANGEL, A.H.N.; URBANO, A.S. et al. Alguns aspectos qualitativos da carne bovina: uma revisão. Acta Vet. Brasilica, v.5, p.351358,2011 
LISTRAT, A.; LEBRET, B.; LOUVEAU, I. et al. How muscle structure and composition influence meat and flesh quality. Sci. World J., v.2016, p.1-14, 2016.

MOBINI, B. Histological properties of intramuscular connective tissues in native chickens and their relationship with meat tenderness. Global Anim. Sci. J., v.2, p.105-109, 2015.

NAKAMURA, Y.N.; IWAMOTO, H.; ONO, Y. et al. Relationship among collagen amount, distribution and architecture in the $\mathrm{M}$. longuissimus toracics and $\mathrm{M}$. pectoralis profundus from pigs. Meat Sci., v.64, p.4350, 2003.

NAKAMURA, Y.N.; IWAMOTO, H.; SHIBA, N. et al. Developmental states of the collagen content, distribution and architecture in the pectoralis, iliotibialis lateralis and puboischiofemoralis muscles of male Red Cornish $\times$ New Hampshire and normal broilers. Br. Poult. Sci., v.45, p.31-40, 2004.

NISHIMURA, R. The role of intramuscular connective tissue in meat texture. Anim. Sci. J., v.81, p.21-27, 2010.

NISHIMURA, T.; OJIMA, K.; LIU, A. et al. Structural changes in the intramuscular connective tissue during development of bovine semitendinosus muscle. Tissue Cell, v.28, p.527-536, 1996.

OSERA, R.H.; DALANEZI, J.A.; JUNQUEIRA, O.M. et al. Effect of the inclusion of digestive enzymes on the yield of noble parts of broilers. Pubvet, v.2, n.23, 2008.

PURSLOW, P.P. Intramuscular connective tissue and its role in meat quality. Meat Sci., v.70, p.435-447, 2005.

RAMOS, E.M.; GOMIDE, L.A.M. Textura e maciez da carne. In: Avaliação da qualidade de carnes - fundamentos e metodologias. Viçosa: UFV, 2007. p.375-454.

ROSTAGNO, H.S.; ALBINO, L.F.T.; DONZELE, J.L et al. Tabelas brasileiras para aves e suínos: composição de alimentos e exigências nutricionais. 3.ed. Viçosa: UFV, 2011. 252p.
SAKAKIBARA, K.; TABATA, S.; SHIBA, N. et al. Myofibre composition and total collagen content in $M$. iliotibialis lateralis and $M$. pectoralis of Silkie and White Leghorn chickens. Br. Poult. Sci., v.41, p.570574,2000

SOUZA, X.R.; FARIA, P.B.; BRESSAN, M.C. Qualidade da carne de frangos caipiras abatidos em diferentes idades. Arq. Bras. Med. Vet. Zootec., v.64, p.479-487, 2012.

TAKAHASHI, S.E.; MENDES, A.A.; SALDANHA, E.S.P.B. et al. Efeito do sistema de criação sobre o desempenho e rendimento de carcaça de frangos de corte tipo colonial. Arq. Bras. Med. Vet. Zootec., v.58, p.624-623, 2006.

TESSERAUD, S.; MAAA, N.; PERESSON, R.; CHAGNEAU, A.M. Relative responses of protein turnover in three different muscles to dietary lysine deficiency in chicks. Br. Poult. Sci., v.37, p.641-650, 1996.

VOUTILA, L.; RUUSUNEN, M.; JOUPPILA, K.; PUOLANNE, E. Thermal properties of connective tissue in breast and leg muscles of chickens and turkeys. J. Sci. Food Agricult., v.89, p.890-896, 2009.

WATANABE, T.; NISHIMURA, K.; TAKEUCHI, R. et al. Oral ingestion of collagen peptide causes change in width of the perimysium of chicken iliotibialis lateralis muscle. J. Vet. Med. Sci., v.77, p.1413-1417, 2015.

WESTON, A.R.; ROGERS, R.W.; ALTHEN, T.G. Review: the role of collagen in meat tenderness. Prof. Anim. Sci., v.18, p.107-111, 2002.

YAMAUCHI, K.; MANABE, N.; MATSUMOTO, Y.; TAKENOYAMA，S.; YAMAUCHI，K. Increased collagen III in culled chicken meat after feeding dietary wood charcoal and vinegar contributes to palatability and tenderness. Anim. Sci. J., v.85, p.468480, 2014

ZANUSSO, J.; DIONELLO, N.J.L. Produção avícola alternativa - análise dos fatores qualitativos da carne de frangos de corte tipo caipira. Rev. Bras. Agrociênc., v.9, p.191-194, 2003. 